\title{
Tetrazolium test for the viability of gherkin seeds ${ }^{1}$
}

\author{
Teste de tetrazólio para avaliação da viabilidade de sementes de maxixe
}

\author{
Emanoela Pereira de Paiva ${ }^{2 *}$, Salvador Barros Torres ${ }^{2}$, João Paulo Nobre de Almeida ${ }^{2}$, Francisco Vanies da Silva Sá ${ }^{3}$ \\ and Renata Ramayane Torquato Oliveira ${ }^{2}$
}

\begin{abstract}
The tetrazolium test is a quick and effective method for evaluating viability in seeds. The aim of this study was to determine a methodology for using the tetrazolium test, and its efficiency in verifying viability in seeds of the gherkin (Cucumis anguria L.). Consequently, five batches of gherkin seed were initially evaluated by the tests for germination, first count and speed of germination. The batches were then subjected to treatments in order to adjust the methodology for the tetrazolium test, evaluating three concentrations of tetrazolium solution $(0.100,0.075$ and $0.050 \%)$, kept in the dark for two, four and six hours, under temperatures of $35{ }^{\circ} \mathrm{C}$ and $40{ }^{\circ} \mathrm{C}$, with four replications of 25 seeds per treatment. At the end of the staining period, the seeds were washed in running water, split lengthways between the cotyledons, and classified as viable and non-viable. Evaluation of viability in seeds of the gherkin by tetrazolium test is efficient when carried out at a concentration of $0.050 \%$, either for six hours at $35^{\circ} \mathrm{C}$ or four hours at $40{ }^{\circ} \mathrm{C}$.
\end{abstract}

Key words: Cucumis anguria. Viability. Vigour. Quick test.

\begin{abstract}
RESUMO - O teste de tetrazólio é um método rápido e eficaz para avaliar a viabilidade das sementes. Este trabalho teve como objetivo determinar a metodologia de execução do teste de tetrazólio e a sua eficiência para verificar a viabilidade em sementes de maxixe (Cucumis anguria L.). Para isso, cinco lotes de sementes de maxixe foram inicialmente avaliados pelo teste de germinação, primeira contagem e velocidade de germinação. Posteriormente os lotes foram submetidos aos tratamentos para adequação da metodologia do teste de tetrazólio, sendo avaliadas três concentrações da solução de tetrazólio $(0,100 ; 0,075$ e $0,050 \%$ ), mantidas no escuro, por duas, quatro e seis horas, sob temperaturas de 35 e $40{ }^{\circ} \mathrm{C}$, com quatro repetições de 25 sementes para cada tratamento. Decorridos os períodos de coloração, as sementes foram lavadas em água corrente, seccionadas longitudinalmente entre os cotilédones e classificados em viáveis e não viáveis. A avaliação da viabilidade de sementes de maxixe pelo teste de tetrazólio é eficiente quando realizada sob concentração de $0,050 \%$ por seis horas a $35^{\circ} \mathrm{C}$ ou quatro horas a $40{ }^{\circ} \mathrm{C}$.
\end{abstract}

Palavras-chave: Cucumis anguria. Viabilidade. Vigor. Teste rápido.

\footnotetext{
DOI: $10.5935 / 1806-6690.20170013$

*Autor para correspondência

${ }^{1}$ Recebido para publicação em 05/01/2016; aprovado em 10/04/2016

Pesquisa desenvolvida no Laboratório de Análise de Sementes da Universidade Federal Rural do Semi-Árido/UFERSA

${ }^{2}$ Departamento de Fitotecnia, Universidade Federal Rural do Semi-Árido, R. Francisco Mota, 572, Costa e Silva, Mossoró-RN, Brasil, 59.600-971, emanuelappaiva@hotmail.com, sbtorres@ufersa.edu.br, joaopaulonobre@yahoo.com.br, renataramayanet@gmail.com

${ }^{3}$ Centro Tecnologia e Recursos Naturais, Universidade Federal de Campina Grande, Rua Aprígio Veloso, 882, Bairro Universitário, Campina Grande-PB, Brasil. 58.429-900, vanies_agronomia@hotmail.com
} 


\section{INTRODUCTION}

Gherkin (Cucumis anguria L.) belongs to the Cucurbitaceae family, which produces fleshy fruits used in cookery, especially in the North and Northeast regions of Brazil. The gherkin crop is considered as secondary, due to its low yield and for having great genetic variability of the cultivated material, which leads to nonuniformity in fruit production and, consequently, production of seeds with low physiological quality (MEDEIROS et al., 2010; OLIVEIRA et al., 2014).

The physiological quality of the seed determines its viability and vigor, which are evaluated through laboratory analyses that express this potential in a precise, rapid and efficient way. For this purpose, the germination test is the most used to verify the viability of seeds and its result represents the maximum potential of the seed lot obtained under favorable environmental conditions (BRASIL, 2009).

Although the germination test is widely used, it has limitations, especially regarding its duration, requiring the use of other faster tests, such as the tetrazolium test. This test has attracted the attention of researchers, because it allows to efficiently estimate viability and vigor of the seeds, besides favoring the identification of factors that influence their quality (GUEDES et al., 2010; MARCOSFILHO, 2015).

Various factors interfere with the tetrazolium test, especially those related to the execution methodology, such as the preparation of seeds before coloration (GASPAROLIVEIRA et al., 2011). The effectiveness of this test in the evaluation of seed vigor and viability depends on the application of appropriate methods for each species, such as the pre-conditioning and cut of the seeds, which are necessary for the penetration of the tetrazolium solution into the embryonic tissues (BRASIL, 2009; GUEDES et al., 2010). However, despite the importance of the pre-conditioning of the seeds, the concentration of the solution, coloration temperature and time of exposure of the seeds are fundamental steps for the adjustment of the methodology of the test to the seed of each species (GASPAR-OLIVEIRA et al., 2011).

Temperature leads to significant gains in the execution time of the test; as it increases, there can be an increment in the speed of seed imbibition and, consequently, in coloration (RODRIGUES et al., 2015). Another aspect considered as important is the concentration of the tetrazolium solution, which may vary from 0.5 to $1.0 \%$ (BRASIL, 2009). However, recent studies with various species have indicated that the use of solution at $0.075 \%$ allows the development of ideal coloration in both vigorous and non-vigorous tissues (BHERING; DIAS;
BARROS, 2005; LIMA; PINTO; NOVEMBRE, 2010; NERY; CARVALHO; OLIVEIRA, 2007; NOGUEIRA; TORRES; FREITAS, 2014).

The period of seed immersion in the tetrazolium solution also influences the results, because the excessive contact time of embryonic tissues with the solution may lead to development of coloration even in dead tissues or a very intense pink color in living tissues, compromising the interpretation and possibly the efficiency of the test (COSTA; SANTOS, 2010; SANTOS; NOVEMBRE; MARCOS-FILHO, 2007; SILVA et al., 2013).

Therefore, this study aimed to determine the methodology of execution of the tetrazolium test and its efficiency to evaluate the viability of gherkin seeds.

\section{MATERIAL AND METHODS}

The experiment was carried out at the Laboratory of Seed Analysis of the Department of Plant Sciences of the Federal Rural University of the Semi-arid Region (UFERSA), Mossoró - RN, Brazil, using five lots of gherkin seeds, variety 'maxixe-do-norte'.

Initially, gherkin seeds were subjected to the following determinations and tests: a) germination conducted with four replicates of 50 seeds, distributed on sheets of paper towel moistened with water in the amount of 2 times the weight of the dry substrate and maintained in a germinator at $25^{\circ} \mathrm{C}$ with photoperiod of $8 \mathrm{~h}$ of light. The evaluations were performed at 4 and 8 days after sowing, determining the percentage of normal seedlings; b) germination speed - performed simultaneously to the germination test, with data obtained daily until 10 days after sowing and calculated according to Maguire (1962).

Preliminary tests were conducted for the determination of water absorption rate by the seeds, aiming at their preparation for coloration in the tetrazolium solution. For that, imbibition temperature (30 and $40{ }^{\circ} \mathrm{C}$ ), seed moistening method (immersion in water and between moistened paper towel) and the period of imbibition (12 and 16 hours) were evaluated. Immersion of the seeds in water at $40{ }^{\circ} \mathrm{C}$ for $16 \mathrm{~h}$ was adopted in the tests, because it was the best procedure of pre-conditioning. Then, the seeds were longitudinally sectioned in the center of the embryonic axis, with later removal of the tegument, and one of the halves of the embryo of each seed was submersed in solution of 2,3,5triphenyltetrazolium chloride, at the concentrations of $0.100,0.075$ and $0.050 \%$, in the dark, at temperatures of 35 and $40^{\circ} \mathrm{C}$ for 2,4 and $6 \mathrm{~h}$, using four subsamples of 25 seeds, inside plastic cups. After the periods of coloration, the solutions were drained and the seeds were washed 
in running water and evaluated for uniformity, location and intensity of coloration of embryonic tissues, being classified into two categories: viable and non-viable (NERY; CARVALHO; OLIVEIRA, 2007).

Viable seeds were considered as those whose embryo showed uniform shiny pink color, tissue with normal aspect, firm, with embryonic axis and cotyledon node region colored and cotyledon with more than 50\% of its surface colored (Figure 1A). Non-viable seeds were those with totally white or intense red color, soft tissues, characterizing dead tissue and seeds with the entire embryonic axis in an intense carmine red (Figure 1BC).

The statistical design used was completely randomized, in a $5 \times 3 \times 3$ factorial scheme (seed lots $\mathrm{x}$ tetrazolium solution concentrations $\mathrm{x}$ periods of seed immersion in the solution), with four replicates. Two experiments were conducted; the first adopted the coloration temperature of $35^{\circ} \mathrm{C}$ and the second adopted the temperature of $40^{\circ} \mathrm{C}$. The obtained results were subjected to analysis of variance and, in case of significance, Tukey test at 0.05 probability level $(p<0.05)$ was applied using the statistical program SISVAR (FERREIRA, 2011) and, subsequently, Pearson's correlation analysis $(p<0.05)$.

\section{RESULTS AND DISCUSSION}

The results of germination, first count and germination speed index of the seeds allowed to infer that the physiological potential of lot 5 was superior to the others. For these analyzed variables, the lots 2, 3 and 4 did not differ statistically and were superior to lot 1 , which showed the worst results (Table 1).

For the follow-up analysis of the factor Lots at temperature of $35^{\circ} \mathrm{C}$, lot 5 was superior to the others, regardless of the evaluated concentrations and periods (Table 2). Lots 2 and 3 also obtained satisfactory results when exposed to the tetrazolium solution for $6 \mathrm{~h}$, at the concentrations of 0.050 and $0.075 \%$. In addition, it was observed that the seeds from lot 1 obtained the lowest percentages of viable seeds. The results found in the present study corroborate those of the germination test, in which lots 1 and 5 showed the lowest and highest vigor, respectively (Table 1 ).

According to the follow-up analysis of the concentration in the interaction Lots $x$ Period, the immersion of the seeds in tetrazolium solution for the different concentrations during the period of $2 \mathrm{~h}$ was not adequate for the evaluation of the viability of gherkin seeds. The concentrations of 0.050 and $0.075 \%$ were the ones that best expressed the viability of the lots, when evaluated in the period of $6 \mathrm{~h}$. The application of this methodology allowed the identification of the lots 5,3 and 2 as those with higher percentage of viable seeds in comparison to the others, which is similar to the results of the germination test (Table 1).

For seeds of cucumber (Cucumis sativus L.), which belongs to the same genus of gherkin, the concentration of $0.075 \%$ of tetrazolium salt was also sufficient to evaluate the viability, but for immersion of $1 \mathrm{~h}$, a period shorter than that found in the present study (LIMA; PINTO; NOVEMBRE, 2010).

Figure 1 - Illustration of gherkin seeds after tetrazolium test: viable (A), non-viable (B) and dead (C)
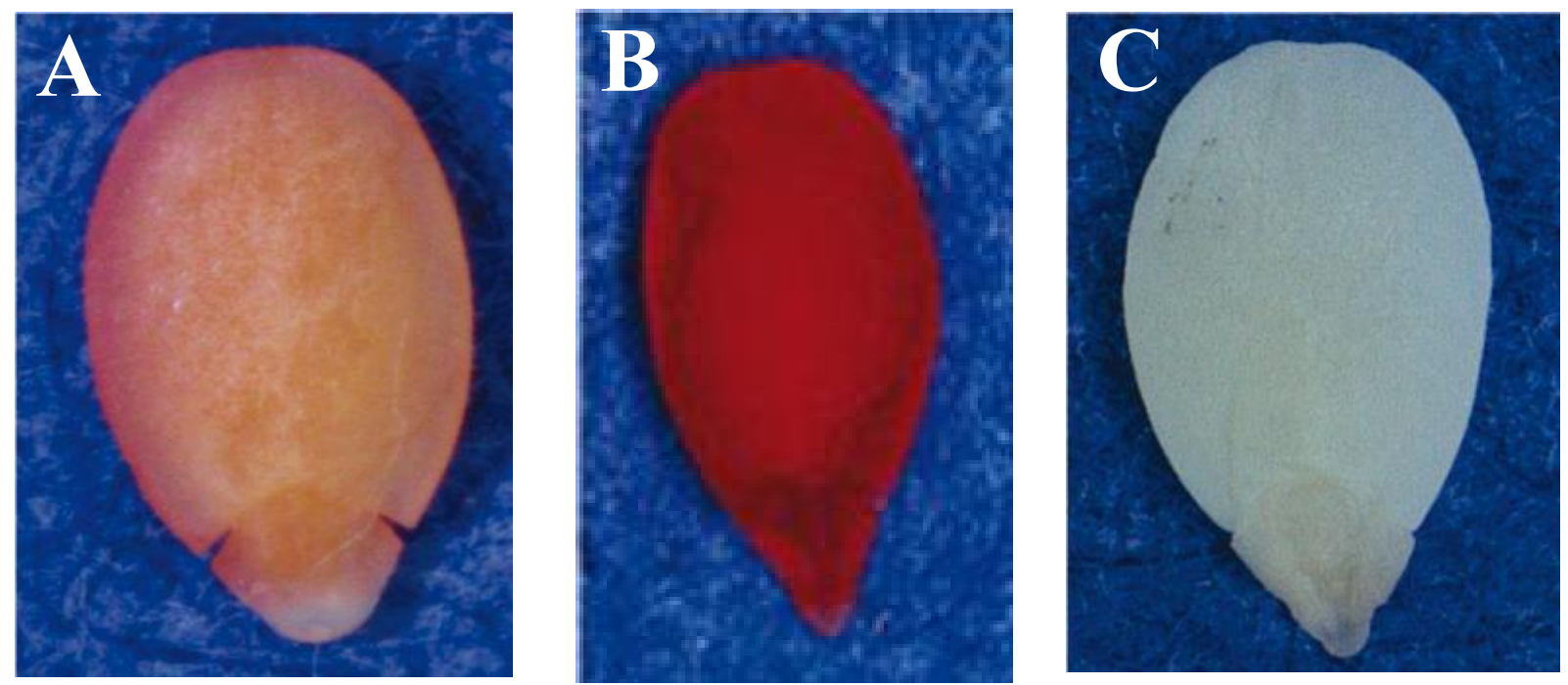
Table 1 - Germination (G), first count of germination (FC) and germination speed index (GSI) for the evaluation of the physiological potential of five lots of gherkin seeds

\begin{tabular}{lccc}
\hline \multicolumn{1}{c}{ Lots } & $\mathrm{G}(\%)$ & $\mathrm{FC}(\%)$ & $\mathrm{GSI}$ \\
\hline 1 & $67 \mathrm{c}$ & $23 \mathrm{~d}$ & $6.9 \mathrm{c}$ \\
2 & $77 \mathrm{bc}$ & $53 \mathrm{c}$ & $10.3 \mathrm{~b}$ \\
3 & $89 \mathrm{ab}$ & $74 \mathrm{~b}$ & $12.6 \mathrm{~b}$ \\
4 & $77 \mathrm{bc}$ & $66 \mathrm{bc}$ & $10.9 \mathrm{~b}$ \\
5 & $92 \mathrm{a}$ & $90 \mathrm{a}$ & $25.3 \mathrm{a}$ \\
Mean & 80.6 & 61.3 & 13.2 \\
$\mathrm{CV}(\%)$ & 7.94 & 9.96 & 8.43 \\
\hline
\end{tabular}

Equal letters in the column do not differ by Tukey test $(p<0.05)$

In the follow-up analysis of the exposure periods, the period of $6 \mathrm{~h}$ promoted higher number of viable seeds for all studied lots, regardless of the concentration used (Table 2). Hence, it can be inferred that, for the tetrazolium test at temperature of $35^{\circ} \mathrm{C}$, it is necessary a longer period of immersion of the seeds in the solution to obtain the adequate coloration pattern, possibly because the utilized temperature does not stimulate higher respiratory activity of the living tissues of the seeds, which may be confirmed with the test at temperature of $40{ }^{\circ} \mathrm{C}$. As to the coloration pattern, the period of exposure of $6 \mathrm{~h}$ and concentration of $0.100 \%$ proved inadequate, since the embryos assumed an intense red color, which may lead to misinterpretation of the results, resulting in underestimation of the viability of the seed lot.

The low concentration of the tetrazolium salt in the solution, combined with the short period of exposure of the seeds $(2 \mathrm{~h})$ at low temperature, was not sufficient to promote the coloration of the living tissues of the seed, especially in the region of the plumule, where the coloration is usually more intense, thus making it difficult the distinction between living and dead tissues, causing lower accuracy in the results of the test (SILVA et al., 2013). Souza et al. (2010) also reported difficulties in the evaluation of essential structures of triticale seeds, using low concentrations and short periods of time.

For the follow-up analysis of the factor Lots at temperature of $40^{\circ} \mathrm{C}$, it was observed that the lots 2,4 and 5 obtained higher number of viable seeds in comparison to the lots 1 and 3 for all concentrations used in the exposure times of 2 and $4 \mathrm{~h}$, respectively. In addition, lot 5 showed the lowest percentage of viable seeds, when exposed to low concentrations of tetrazolium in the longest period of exposure (Table 3). Compared with the

Table 2 - Percentage of viable seeds of gherkin in the tetrazolium test for different combinations of immersion period and concentrations of the solution at temperature of $35^{\circ} \mathrm{C}$

\begin{tabular}{lccccccccc}
\hline \multirow{2}{*}{ Lots } & \multicolumn{3}{c}{2 hours } & \multicolumn{3}{c}{4 hours } & \multicolumn{3}{c}{6 hours } \\
\cline { 2 - 10 } & 0.050 & 0.075 & 0.100 & 0.050 & 0.075 & 0.100 & 0.050 & 0.075 & 0.100 \\
\hline 1 & $36 \mathrm{abAy}$ & $29 \mathrm{bAx}$ & $24 \mathrm{aAx}$ & $40 \mathrm{bAxy}$ & $36 \mathrm{bAx}$ & $31 \mathrm{bAx}$ & $54 \mathrm{cAx}$ & $41 \mathrm{dABx}$ & $35 \mathrm{bCx}$ \\
2 & $34 \mathrm{bAy}$ & $25 \mathrm{bAz}$ & $27 \mathrm{aAy}$ & $64 \mathrm{aAx}$ & $52 \mathrm{bBy}$ & $42 \mathrm{abBxy}$ & $73 \mathrm{abAx}$ & $71 \mathrm{bcAx}$ & $54 \mathrm{aBx}$ \\
3 & $39 \mathrm{abAy}$ & $34 \mathrm{abAy}$ & $27 \mathrm{aAy}$ & $53 \mathrm{bAy}$ & $38 \mathrm{bAy}$ & $28 \mathrm{bAy}$ & $74 \mathrm{abBx}$ & $91 \mathrm{aAx}$ & $58 \mathrm{aCx}$ \\
4 & $29 \mathrm{bAy}$ & $30 \mathrm{abAy}$ & $27 \mathrm{aAx}$ & $51 \mathrm{abAx}$ & $43 \mathrm{bAxy}$ & $39 \mathrm{abAx}$ & $57 \mathrm{bAx}$ & $57 \mathrm{cdAx}$ & $24 \mathrm{bBx}$ \\
5 & $52 \mathrm{aAy}$ & $57 \mathrm{aABy}$ & $35 \mathrm{aBy}$ & $65 \mathrm{aABy}$ & $73 \mathrm{aBx}$ & $55 \mathrm{aBx}$ & $81 \mathrm{aAx}$ & $80 \mathrm{abAx}$ & $69 \mathrm{aAx}$ \\
\hline DMS $^{1}$ & & & & & 17.57 & & & & \\
DMS $^{2}$ & & & & 15.07 & & & & \\
DMS $^{3}$ & & & & 15.07 & & & & \\
\hline
\end{tabular}

${ }^{1}$ Means followed by the same lowercase letter $(\mathrm{a}, \mathrm{b}, \mathrm{c})$ in the column do not differ for the follow-up analysis of the factor Lots by Tukey test (p<0.05). ${ }^{2}$ Means followed by the same uppercase letter (A, B, C) in the row do not differ for the follow-up analysis of the factor Concentration by Tukey test $(\mathrm{p}<0.05) .{ }^{3}$ Means followed by the same letter $(x, y z)$ in the row (correlating the same temperature) do not differ for the follow-up analysis of the factor Immersion period in the solution by Tukey test $(\mathrm{p}<0.05)$ 
Table 3 - Percentage of viable seeds of gherkin obtained through the tetrazolium test for different combinations of immersion period and concentrations of the solution at temperature of $40^{\circ} \mathrm{C}$

\begin{tabular}{lccccccccc}
\hline \multirow{2}{*}{ Lots } & \multicolumn{3}{c}{2 hours } & \multicolumn{3}{c}{4 hours } & \multicolumn{3}{c}{6 hours } \\
\cline { 2 - 9 } & 0.050 & 0.075 & 0.100 & 0.050 & 0.075 & 0.100 & 0.050 & 0.075 & 0.100 \\
\hline 1 & $52 \mathrm{bcAy}$ & $47 \mathrm{bcAy}$ & $35 \mathrm{bcAx}$ & $58 \mathrm{bAy}$ & $59 \mathrm{bcAxy}$ & $34 \mathrm{cBx}$ & $80 \mathrm{abAy}$ & $78 \mathrm{abAx}$ & $52 \mathrm{bBx}$ \\
2 & $61 \mathrm{abAx}$ & $61 \mathrm{abAx}$ & $65 \mathrm{aAx}$ & $65 \mathrm{abAx}$ & $77 \mathrm{abAx}$ & $65 \mathrm{aAx}$ & $60 \mathrm{bAx}$ & $76 \mathrm{abAx}$ & $74 \mathrm{abAx}$ \\
3 & $34 \mathrm{cAz}$ & $29 \mathrm{cAy}$ & $22 \mathrm{cAy}$ & $67 \mathrm{abAy}$ & $43 \mathrm{cBy}$ & $37 \mathrm{bcBy}$ & $97 \mathrm{aAx}$ & $83 \mathrm{aABx}$ & $64 \mathrm{abBx}$ \\
4 & $50 \mathrm{bcAy}$ & $54 \mathrm{abAy}$ & $54 \mathrm{abAx}$ & $67 \mathrm{abAy}$ & $70 \mathrm{abAxy}$ & $59 \mathrm{abAx}$ & $91 \mathrm{aAx}$ & $78 \mathrm{abABy}$ & $67 \mathrm{abBx}$ \\
5 & $82 \mathrm{aAx}$ & $73 \mathrm{aAxy}$ & $67 \mathrm{aAxy}$ & $88 \mathrm{aAx}$ & $85 \mathrm{aAx}$ & $51 \mathrm{abcBy}$ & $58 \mathrm{bAy}$ & $58 \mathrm{bAy}$ & $78 \mathrm{aAx}$ \\
DMS $^{1}$ & & & & & 24.27 & & & & \\
DMS $^{2}$ & & & & & 20.82 & & & & \\
DMS $^{3}$ & & & & & & & & &
\end{tabular}

${ }^{1}$ Means followed by the same lowercase letter $(\mathrm{a}, \mathrm{b}, \mathrm{c})$ in the column do not differ for the follow-up analysis of the factor Lots by Tukey test (p<0.05). ${ }^{2}$ Means followed by the same uppercase letter (A, B, C) in the row do not differ for the follow-up analysis of the factor Concentration by Tukey test $(\mathrm{p}<0.05) .{ }^{3}$ Means followed by the same letter $(x, y$ z) in the column (correlating the same concentration) do not differ for the follow-up analysis of the factor Exposure period by Tukey test $(\mathrm{p}<0.05)$

results obtained in the reference tests of physiological potential (Table 1), the tetrazolium test at temperature of $40{ }^{\circ} \mathrm{C}$ (Table 3 ), conducted in the periods of 2 and $6 \mathrm{~h}$, underestimated and overestimated, respectively, the viability of gherkin seeds, because these conditions led to the non-coloration of living embryos and coloration of dead embryos, respectively.

As to the follow-up analysis of the factor Concentration, there was no significant difference in the concentrations used for the period of $2 \mathrm{~h}$. However, the concentrations of 0.050 and $0.075 \%$, for the period of $6 \mathrm{~h}$, underestimated the viability of the seed lots, except for lot 5 , which was considered as non-viable due to the higher degree of coloration. However, the immersion of the seeds in solution with concentration of $0.050 \%$ for $4 \mathrm{~h}$ allowed adequate coloration and more precise identification of the viable seeds of the lots, a result similar to those obtained in the germination test (Table 1). Since the response of the tetrazolium test depends on the concentration and period of immersion of the seeds in the solution at adequate temperature, when the concentration of $0.050 \%$ was used, the viable tissues developed a little lighter pink color, not interfering with the interpretation of the test during the first $4 \mathrm{~h}$ of exposure. For Sarmento et al. (2013), the use of tetrazolium solution at $0.050 \%$ for $2 \mathrm{~h}$, at $40{ }^{\circ} \mathrm{C}$, was efficient for the coloration of Brazilian guava seeds, corroborating the results observed in the present study, also denoting that the temperature of $40{ }^{\circ} \mathrm{C}$ requires lower tetrazolium concentrations for the test.

The Rules for Seed Analysis recommend the use of tetrazolium solution at $1 \%$ under $30^{\circ} \mathrm{C}$ for 6 to $24 \mathrm{~h}$ for the coloration of embryos of seeds of species from the genus Cucumis for the evaluation of viability (BRASIL, 2009). Temperatures of 35 and $40{ }^{\circ} \mathrm{C}$ were used in the present study in order to decrease the duration of the test; however, the use of higher temperatures did not allow the utilization of tetrazolium solution at $1 \%$ in the present study, for promoting intense colorations in the entire extension of the embryo, thus denoting the non-viability of the seeds. Different results were obtained by Deminics et al. (2014), who observed that the concentration of the tetrazolium solution at $1.0 \%$ for $150 \mathrm{~min}$ allowed to evaluate the viability of the lots of velvet bean seeds even at low temperatures, which can be related to some intrinsic characteristic of the species.

As to the period of immersion of the seeds in the solution at temperature of $40{ }^{\circ} \mathrm{C}$, the immersion for $2 \mathrm{~h}$ did not promote sufficient coloration for the identification of the viability of gherkin seeds, possibly due to the short time of exposure to the tetrazolium solution. On the other hand, the exposure of the seeds for $6 \mathrm{~h}$ promoted greater coloration and may induce the overestimation of the viability of the lots by the seed analyst, probably due to the intense coloration caused by the long time of exposure. Thus, the intermediate time of $4 \mathrm{~h}$ stood out as ideal, for expressing higher similarity between the vigor observed through the tetrazolium test and the vigor in the germination test, especially at the concentration of $0.050 \%$, in which the lots 5, 2, 3 and 4 were considered as viable and lot 1 as non-viable (Tables 1 and 3). Coloration of wheat seeds through immersion $\left(2 \mathrm{~h}\right.$, at $\left.40{ }^{\circ} \mathrm{C}\right)$ in a tetrazolium solution at $0.075 \%$ was recommended for the identification and rejection of lots with lower viability (CARVALHO et al., 2013). 
The highest values of Pearson's correlation index were observed in the tetrazolium test at concentration of $0.050 \%$ for $6 \mathrm{~h}$ of exposure, at temperature of $35^{\circ} \mathrm{C}$, and at concentration of $0.050 \%$ for $4 \mathrm{~h}$ at temperature of $40{ }^{\circ} \mathrm{C}$ (Table 4).

The correlation analysis corroborates the obtained results, indicating that there is potential of use of the tetrazolium test for the identification of the viability of gherkin seeds. In addition, it is observed that the use of the temperature of $40{ }^{\circ} \mathrm{C}$ reduced the duration of the tetrazolium test, possibly due to the increase in the speed of respiration of embryonic tissues, activity of the dehydrogenase enzymes involved in this process and the amount of formazan formed inside the cells, because the increment in temperature accelerates the metabolic reaction of the seeds (BRASIL, 2009; GUEDES et al., 2010; RODRIGUES et al., 2015).

Regarding the concentration, it was observed that the concentration of $0.050 \%$ of tetrazolium solution is the most adequate for the test, with possibility of using the solution concentrated at $0.075 \%$, but with lower precision (Table 4). However, the concentration of $0.100 \%$ proved inappropriate for both temperatures. These results were similar to those observed in other studies with respect to the evaluation of seed viability (COSTA; SANTOS, 2010; NERY; CARVALHO; OLIVEIRA, 2007; NOGUEIRA; TORRES; FREITAS, 2014; SANTOS; NOVEMBRE; MARCOS-FILHO, 2007).

Table 4 - Pearson's correlation between the tetrazolium test and the values of germination (G), first count of germination (FC) and germination speed index (GSI) of gherkin seeds

\begin{tabular}{|c|c|c|c|c|}
\hline \multicolumn{5}{|c|}{ Temperature of $35^{\circ} \mathrm{C}$} \\
\hline Periods (h) & Concentration (\%) & G & $\mathrm{FC}$ & GSI \\
\hline \multirow{3}{*}{2} & 0.050 & $0.5723 * *$ & $0.4988^{*}$ & $0.8213 * *$ \\
\hline & 0.075 & $0.3564^{\mathrm{ns}}$ & $0.4771^{*}$ & $0.5891 * *$ \\
\hline & 0.100 & $0.6969 * *$ & $0.6658 * *$ & $0.6529 * *$ \\
\hline \multirow{3}{*}{4} & 0.050 & $0.6018^{* *}$ & $0.6497 * *$ & $0.8570 * *$ \\
\hline & 0.075 & $0.4996^{*}$ & $0.6414 * *$ & $0.9097 * *$ \\
\hline & 0.100 & $0.4351^{\mathrm{ns}}$ & $0.5467 *$ & $0.7854 * *$ \\
\hline \multirow{3}{*}{6} & 0.050 & $0.7813^{* *}$ & $0.7265^{* *}$ & $0.8263 * *$ \\
\hline & 0.075 & $0.6301 * *$ & $0.5269^{*}$ & $0.6705^{* *}$ \\
\hline & 0.100 & $0.5642 * *$ & $0.6827 * *$ & $0.5256^{*}$ \\
\hline \multicolumn{5}{|c|}{ Temperature of $40^{\circ} \mathrm{C}$} \\
\hline Periods (h) & Concentration (\%) & PG & $\mathrm{FC}$ & GSI \\
\hline \multirow{3}{*}{2} & 0.050 & $0.1977^{\mathrm{ns}}$ & $0.2980^{\text {ns }}$ & $0.6881 * *$ \\
\hline & 0.075 & $0.0206^{\mathrm{ns}}$ & $0.2077^{\mathrm{ns}}$ & $0.4988^{*}$ \\
\hline & 0.100 & $-0.0491^{\mathrm{ns}}$ & $-0.0887^{\mathrm{ns}}$ & $-0.4539 *$ \\
\hline \multirow{3}{*}{4} & 0.050 & $0.6365^{* *}$ & $0.7631 * *$ & $0.9054 * *$ \\
\hline & 0.075 & $0.5610 * *$ & $0.6782 * *$ & $0.6165 * *$ \\
\hline & 0.100 & $0.0217^{\mathrm{ns}}$ & $0.2691^{\mathrm{ns}}$ & $0.4955^{*}$ \\
\hline \multirow{3}{*}{6} & 0.050 & $0.0864^{\mathrm{ns}}$ & $0.2755^{\mathrm{ns}}$ & $0.4230^{\mathrm{ns}}$ \\
\hline & 0.075 & $0.0898^{\mathrm{ns}}$ & $0.2902^{\mathrm{ns}}$ & $0.1481^{\mathrm{ns}}$ \\
\hline & 0.100 & $-0.3468^{\text {ns }}$ & $-0.4295^{\mathrm{ns}}$ & $-0.7449 * *$ \\
\hline
\end{tabular}

Ns $*$ and $* *=$ not significant and significantat 1 and $5 \%(\mathrm{p}<0.01$ and $\mathrm{p}<0.05)$ probability, respectively 


\section{CONCLUSIONS}

The evaluation of viability of gherkin seeds through the tetrazolium test is efficient when performed at concentration of $0.050 \%$ for $6 \mathrm{~h}$ at $35^{\circ} \mathrm{C}$ or for $4 \mathrm{~h}$ at $40^{\circ} \mathrm{C}$.

\section{REFERENCES}

BHERING, M. C.; DIAS, D. C. F. S.; BARROS, D. I. Adequação da metodologia do teste de tetrazólio para avaliação da qualidade fisiológica de sementes de melancia. Revista Brasileira de Sementes, v. 27, n. 1, p. 176-182, 2005.

BRASIL. Ministério da Agricultura, Pecuária e Abastecimento. Regras para análise de sementes. Ministério da Agricultura, Pecuária e Abastecimento. Secretaria de Defesa Agropecuária. Brasília: MAPA: ACS, 2009. 395 p.

CARVALHO, T. C. et al. Tetrazolium test adjustment for wheat seeds. Journal of Seed Science, v. 35, n. 3, p. 361-367, 2013.

COSTA, C. J.; SANTOS, C. P. Teste de tetrazólio em sementes de leucena. Revista Brasileira de Sementes, v. 32, n. 2, p. 066-072, 2010

DEMINICS, B. et al. Tetrazolium test to evaluate Stizolobium aterrimum seeds quality. American Journal of Plant Sciences, v. 5, n. 1, p. 148-152, 2014.

FERREIRA, D. F. Sisvar: a computer statistical analysis system. Ciência e Agrotecnologia, v. 35, n. 6, p. 1039-1042, 2011.

GASPAR-OLIVEIRA, C. M. et al. Pré-condicionamento das sementes de mamoneira para o teste de tetrazólio. Acta Scientiarum Agronomy, v. 33, n. 2, p. 303-311, 2011.

GUEDES, R. S. et al. Metodologia para teste de tetrazólio em sementes de Amburana cearensis (Allemao) A. C. Smith. Revista Brasileira de Plantas Medicinais, v. 12, n. 1, p. 120-126, 2010.

LIMA, L. B.; PINTO, T. L. F.; NOVEMBRE, A. D. L. C. Avaliação da viabilidade e do vigor de sementes de pepino pelo teste de tetrazólio. Revista Brasileira de Sementes, v. 32, n. 1 p. 060-068, 2010.
MAGUIRE, J. D. Speed of germination-aid selection and evaluation for seedling emergence and vigor. Crop Science, v. 2, n. 2, p. 176-177, 1962.

MARCOS-FILHO, J. Fisiologia de sementes de plantas cultivadas. 2. ed. Londrina: Abrates, 2015. 659 p.

MEDEIROS, M. A. et al. Maturação fisiológica de sementes de maxixe (Cucumis anguria L.). Revista Brasileira de Sementes, v. 32, n. 3 p. 17-24, 2010.

NERY, M. C.; CARVALHO, M. L. M; OLIVEIRA, L. M. Teste de tetrazólio para avaliação da qualidade fisiológica de sementes de melancia. Semina: Ciências Agrárias, v. 28, n. 3, p. 365-372, 2007.

NOGUEIRA, N. W.; TORRES, S. B.; FREITAS, R. M. O. Teste de tetrazólio em sementes de timbaúba. Semina: Ciências Agrárias, v. 35, n. 6, p. 2967-2976, 2014.

OLIVEIRA, F. A. et al. Produtividade do maxixeiro cultivado em substrato e fertirrigado com soluções nutritivas. Horticultura Brasileira, v. 32, n. 4, p. 464-467, 2014.

RODRIGUES, A. P. M. S. et al. Teste de tetrazólio para avaliação da qualidade fisiológica de sementes de Vigna unguiculata (L.) Walp. Revista Ciência Agronômica, v. 46, n. 3, p. 638-644, 2015.

SANTOS, M. A. O.; NOVEMBRE, A. D. L. C.; MARCOSFILHO, J. Tetrazolium test to assess viability and vigour of tomato seeds. Seed Science and Technology, v. 35, n 1, p. 213223, 2007.

SARMENTO, M. B. et al. Teste de tetrazólio para avaliação da qualidade fisiológica em sementes de goiabeira-serrana (Acca sellowiana O. Berg Burret). Revista Brasileira de Fruticultura, v. 35, n. 1, p. 270-276, 2013.

SILVA, R. C. et al. Adaptação do teste de tetrazólio para avaliação da viabilidade e do vigor de sementes de girassol. Pesquisa Agropecuária Brasileira, v. 48, n. 1, p. 105-113, 2013.

SOUZA, C. R. et al. Tetrazolium test for evaluating triticale seed viability. Revista Brasileira de Sementes, v. 32, n. 3, p. 163$169,2010$. 